\title{
Orthodoxy, Autocracy, Nationality: Georgy Sviridov‘s Russia Cast Adrift
}

\author{
Richard Louis Gillies \\ Martin Harris Centre for Music and Drama \\ University of Manchester \\ Manchester, United Kingdom \\ E-mail: richard.gillies@manchester.ac.uk
}

\begin{abstract}
This article presents an overview of research on Georgy Sviridov's 1977 vocal cycle Russia Cast Adrift undertaken during the writing of my doctoral thesis (awarded by the University of Manchester in July 2018). The discussion focuses on Sviridov's response to bucolic and religious themes in Esenin's poetry. Ultimately it is suggested that Sviridov's engagement with such themes allows the work to be understood as a musical analogue to developments in literature, visual art, and film that were representative of a burgeoning Russian nationalist movement in the post-Stalinist era. This allows for a more nuanced characterisation of Sviridov and his music than is commonly acknowledged in English-language musicology.
\end{abstract}

Keywords-Georgy Sviridov; Russian nationalism; Soviet culture; music and poetry; music and society

\section{INTRODUCTION}

From his earliest compositions Georgy Sviridov embraced the art-song genre and remained a prolific composer of songs and vocal music throughout his career until his death in 1998. His vocal cycle Russia Cast Adrift ${ }^{1}$ was completed in 1977 and features a setting of twelve poems by Sergei Esenin (1895-1925). Described as the self-styled tast poet of Wooden Russia"“ [1], Esenin enjoyed immense popularity during his short lifetime. Common subjects in his poetry include rural Russia, the Russian peasantry, Russian Orthodoxy and mysticism, the evils of industrialisation, and the elevation of what he described as Wooden Russia', that is, traditional, preindustrial Russia before the Bolshevik worship of iron and steel. This article first considers the ways in which such sentiments became a fundamental aspect of the Russian nationalist movement(s) that emerged in the post-Stalinist era, before seeking to identify traces of this cultural context within Sviridov's music itself.

\section{RUSSIAN NATIONALISM IN SOVIET CUltuRE}

A number of English-language academic publications, including those by Yitzhak M. Brudny, Simon Cosgrove,

The Russian title 'Otchalivshaya Rus' is variously translated into English as Russia Adrift,' Russia Cast Off,' and even Russia Off Her Mooring.
Vladislav Zubok, and Jeremy Smith have examined the significance of Russian nationalist sentiments that began to seep into public discourse during the post-Stalinist era. This came partly as a result of the relaxation of censorship during the so-called Thaw'. Indeed, Cosgrove has described Khrushchev's premiership as the germinal stage in the development of post-war Russian nationalism' and suggests that, during this period,

intellectuals were able to reassess in relative freedom... their attitudes on many issues, including Russian and Soviet history, the Orthodox Church, the legitimacy of the Soviet regime, Stalin, and the tremendous social changes wrought by Soviet power ... as a result of rapid and forced state-led processes of modernization (urbanization, collectivization and the destruction of traditional beliefs and ways of life) [2].

One of the major literary movements to emerge from this period was Village Prose [Derevenskaya proza], which began to coalesce from 1953 onwards, its primary focus being the exploration of the historical, political, and sociological dimensions of the peasant existence" [3]. Brudny describes this distinct group of social critics' as becoming the voice of Russian nationalist sentiment and a starting point for the development of the Russian nationalist movement" [3], while Cosgrove has suggested that, [i]mplicit in the works of the -illage prose" writers was a nostalgia for a vanished rural, ethnically Russian Golden Age' [2] (hence the reference to Nicholas I's maxim in the title of this article). This certainly seems to echo the opinion of the novelist Sergei Zalygin (a key figure of the Village Prose movement) who, in 1969, described his motivation as a writer of Village Prose thus:

I feel that the roots of my nation are, indeed, in the village, in the ploughed field, in daily bread. Furthermore, it seems that our generation will have been the last to see with its own eyes the one-thousand-yearold (peasant) way of life, in which each of us grew up. If we do not tell about it and its radical alteration in a short period of time, who will? [4]

Similarly, though he was not directly associated with Village Prose, the poet and erstwhile editor of Noviy mir Aleksandr Tvardovsky has been described by Vladislav 
Zubok as being haunted by the tragic fate of the Russian peasantry and the death between 1929 and 1953 of the traditional Russian way of life" [5]. Sviridov was a great admirer of Tvardovsky's poetry, placing him alongside Pushkin, Blok, Esenin, and others [6], and it is worth highlighting a stark resonance between the sentiments attributed to Tvardovsky above and Sviridov's own summary of Russia Cast Adrift in his diaries where he refers explicitly to revolutionary upheaval and the death of the native home', and to the death of the patriarchal peasant way of life' [6].

Another major feature of the post-Stalinist Russian nationalist movement(s) was a deep interest in traditional Christian practices and the revival of the Orthodox Church. This included the preservation and reconstruction of old churches and cathedrals, many of which had faced destruction during both Stalin's and Khrushchev's antireligious campaigns of 1929-1932 and 1959-1964 respectively. Perhaps the most famous example of this impulse to preserve and restore Russian historical monuments and churches was Ilya Glazunov's appeal, in 1962, for the reconstruction of the Cathedral of Christ the Saviour in Moscow that had been destroyed in 1931 [5]. While the studies mentioned thus far (particularly those by Brudny and Cosgrove) have focused primarily on developments in literature, it is clear that thematic topics such as the traditional Russian peasantry and Orthodox Christianity, whether or not one wishes to describe them specifically as nationalist", are also present in many other cultural products of the period. For instance, in the world of cinema (a highly important medium in the history of Soviet culture) one need only look as far as Andrei Tarkovsky's astounding portrayal of the mediaeval icon painter Andrei Rubliev in a film that, in the words of Martin Sixsmith, illustrates the hold that Orthodox Christianity exerts on the Russian consciousness' [7]. Though most evident in Andrei Rubliev, the important role of Christian spirituality and mysticism in Russian culture is also beautifully encapsulated in the final shot of Tarkovsky's Nostalgia that portrays the traditional Russian home within the ruins of an Italian cathedral.

This is precisely the cultural milieu in which Sviridov was composing Russia Cast Adrift, and a vast amount of his artistic output from this period can and arguably should (given its explicit engagement with rural, religious, and prerevolutionary ideas) be understood as a musical equivalent to the burgeoning Russian nationalist movement that was emerging in literary journals and other cultural media. Through identifying with nationalist preoccupations, Sviridov, like his literary counterparts, created his own cultural identity and a sense of both personal and artistic autonomy from the purely Marxist-Leninist ideology officially touted by the regime.

So how do such Russian nationalist themes and ideas manifest themselves in Sviridov's Russia Cast Adrift? Identifying the traces of this cultural context within the music itself is not always an easy matter given the relatively abstract nature of the art form. Nonetheless, the second half of this article seeks to elucidate this matter by considering some of the key thematic features that can be found throughout the cycle.

\section{THEMATIC STRANDS IN RUSSIA CAST ADRIFT: BETRAYAL AND RESURRECTION ${ }^{2}$}

Sviridov had a particular affinity for Esenin's verse. He considered it to be expressive of the deepest element of the Russian soul, its pathos being bound inextricably not only to Esenin's own tragic biography but also to the fate of the Russian people in the wake of revolutionary upheaval. Indeed, in a diary entry from the early 1980s, Sviridov described Esenin's poetry as being inseparable from the soul of the people', and Esenin himself as the poet of the people - a people perishing in trenches, camps, prisons, barracks and taverns' [6]. Seven of the songs in Russia Cast Adrift are settings of short poems in their entirety, while the remaining five are derived from longer poems, edited down to fit into short song structures. All twelve poems were published independently of each other over a period of six years between 1914 and 1920. Though they were not originally conceived as part of any larger cycle by Esenin, there are strong thematic and symbolic links between them, particularly in their intermingling of pastoral and religious imagery, suggesting that Sviridov chose them carefully in order to serve his own aesthetic.

Russia Cast Adrift is thoroughly representative of Sviridov's mature compositional language, described by the composer himself as being truly Russian music - a new, bright, crystal-clear style ${ }^{6}[6]$. The harmonic language throughout the cycle is predominantly pandiatonic, making use of brightly coloured cluster chords which often revolve around a pedal, and which usually develop out of single notes, perfect fourths or fifths, or consonant diatonic chords. This creates a shimmering, ever-expanding, somewhat tintinnabular effect, as if the initial note(s) or consonant harmonies progressively acquire more overtones as a result of repeated striking. This musical evocation of bells and chimes is crucial to the cycle as a whole when considered alongside the overt religious references, often in direct conjunction with pastoral imagery, found in the Esenin poems set, and it is worth noting that the direction belllike' [kolokol'no] appears more than once in the cycle.

The potent mixture of pastoral and religious imagery is a salient characteristic of the cycle as a whole. This is clearly exemplified in the very first song, a setting of Esenin's 1914 poem, Autumn', which, through its pensive evocation of the autumnal Russian landscape in conjunction with references to the red sores of the invisible Christ ${ }^{\circ}$ [ Язвы красные незримому Христу'], invests the natural features of the Russian country itself with an innately spiritual, messianic quality. The connotations of martyrdom, betrayal, sacrifice and rebirth associated with any references to the gospels are worth keeping in mind, since over the course of the cycle, two parallel thematic strands emerge: betrayal and

\footnotetext{
Some of the ideas in this section also appear in my forthcoming article for the Slavonic and East European Review, Otchalivshaia Rus': Georgii Sviridov and the Soviet Betrayal of Rus' (forthcoming, Spring 2019).
} 
suffering on the one hand, and resurrection, transcendence, and faith in Russia itself on the other.

Autumn', strongly links the natural characteristics of the Russian landscape to religious symbols — to the Orthodox church, to Christ, and to the stigmata. In addition to musical similarities, linguistic features bind Autumn' to the third song, Open Before Me, Guardian Beyond the Clouds', particularly the reference to the red mare" [рыжая кобыла'] in the former, and to my horse' [_конь мой“] in the latter. In Autumn' the mare is a symbol of the autumnal Russian landscape, invested with innate spiritual qualities. In Open Before $\mathrm{Me}^{c}$, the horse is associated with strength ' and power', and, as Sviridov suggests in his diaries, with poetic creativity [6]. What emerges is a composite symbol of nature, religion, Orthodoxy, tradition, culture, strength, and power ultimately an evocation of pre-revolutionary rural Russia. In the sixth song, Simon, Peter... Where Are You? Come to $\mathrm{Me}^{6}$, musical and literary resonances with both Autumn" and Open Before Me' link all three songs to the betrayal of Christ. This is particularly evident in Sviridov's setting of the word Judas' [ЦИуда'] to the leap of a perfect fourth - an interval once described by Mikhail Glinka as the soul of Russian music' [8], and which is a prominent melodic characteristic of both Autumn' and Open Before $\mathrm{Me}^{6}$ in "Fig. 1", "Fig. 2" and "Fig. 3". There is also a linguistic echo between Autumn' and Simon, Peter' in the use of the word red(-haired)' [рыжий']; as Christ is indelibly linked to Judas in the gospel, so the red mare ' of Autumn' is linked to the red-haired fisherman'[рыжий рыбак']of Simon, Peter'.

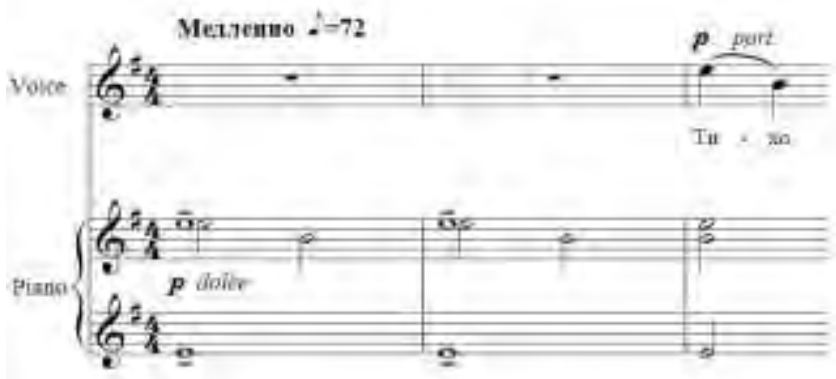

Fig. 1. Sviridov, Russia Cast Adrift, Autumn', bars 1-3.

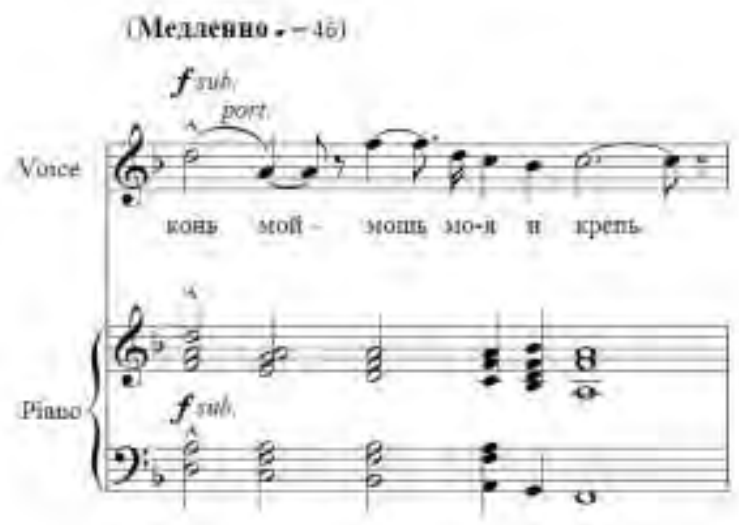

Fig. 2. Sviridov, Russia Cast Adrift, Open Before Me', bar 5 .

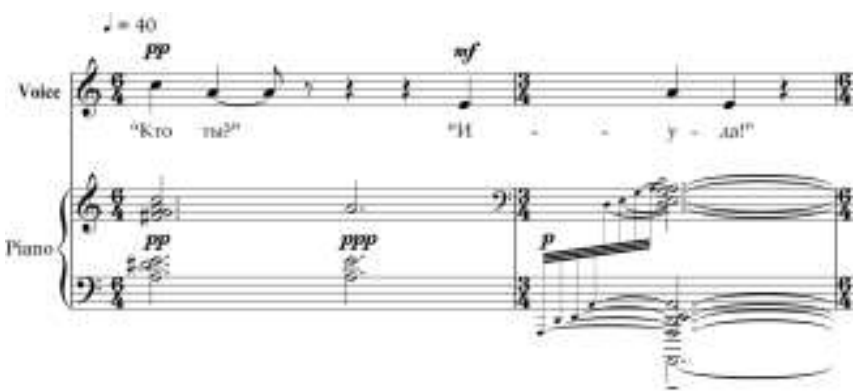

Fig. 3. Sviridov, Russia Cast Adrift, Simon, Peter...', bars 36-37.

Thus, two interlocked narratives emerge in parallel: a symbolistic pastoral-religious retelling of the betrayal of Christ in the gospels, and an allegorical polemic in which the betrayal of Christ is associated with the systematic destruction of the traditional patriarchal Orthodox society of rural Russia during the Soviet era. This is particularly evident in the apocalyptic tone of the seventh and ninth songs, Where, Where Are you, Paternal Home?' and It Sounds, It Sounds, the Fateful Horn!'. As noted above, Sviridov described these songs respectively in his diaries as, a picture of revolutionary upheaval, the death of the native home', and a tragic monologue. A tragic feeling of the death of the patriarchal peasant way of life" [6]. Both songs open with an echo of the falling fourth that features so prominently in Autumn', Open Before $\mathrm{Me}^{\circ}$, and Simon, Peter' in "Fig. 4" and "Fig. 5", cf. "Fig. 1", "Fig. 2" and "Fig. 3". Symbolic images of a cock crowing [За рекой поет петух '] and a shepherd watching over his flock [_Там стада стерег пастух'] in Where Are You, Paternal Home', further strengthen the link to the Christian gospels, while in It Sounds, It Sounds', the fateful horn' of Esenin's poem can be perceived as an equation of the seven trumpet calls that herald the destruction of the world in Christian doctrine with the encroaching steam whistle of industrialisation Esenin's beloved _Wooden Russia' destroyed by the coming of a new, industrial world. At the dramatic apex of the song, vicious dissonances underpin the lines There he is, there he is with his iron belly, / Stretching his fingers out towards the throat of the planes', Sviridov effectively choking all 
semblance of diatonic consonance from his harmonic language in a vivid musical response to Esenin's poetic imagery.

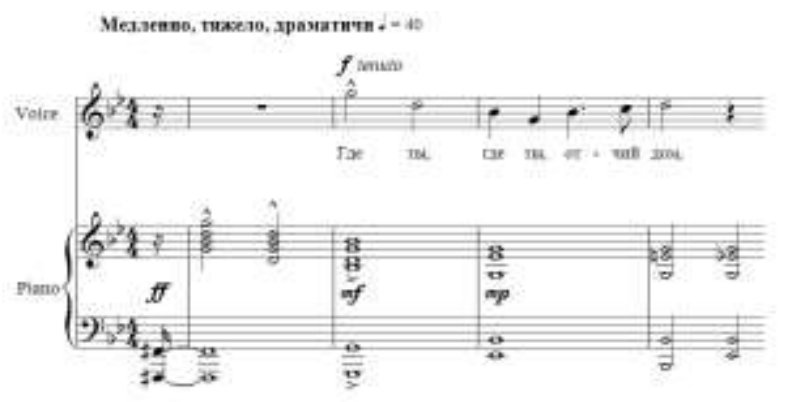

Fig. 4. Sviridov, Russia Cast Adrift, _Where, Where Are You, Paternal Home?', bars 1-4.

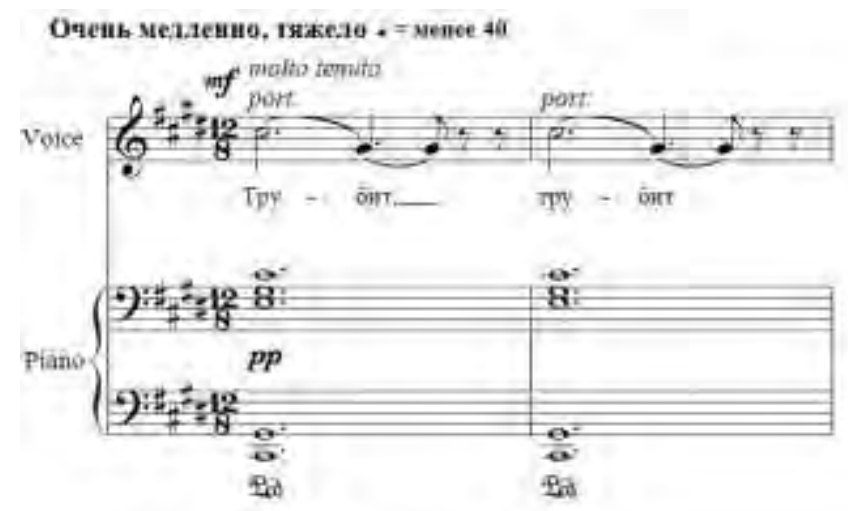

Fig. 5. Sviridov, Russia Cast Adrift, It Sounds, It Sounds, the Fateful Horn!', bars 5-6.

But these themes of loss, suffering, and betrayal are counterbalanced and ultimately superseded by themes of transcendence, transfiguration, resurrection, and faith in the glory of Sviridov's messianic Rus', most prominent in the fifth, eighth, eleventh and twelfth songs of the cycle. This counter-narrative is evident on multiple levels: in the selection of Esenin's verses, in the musical settings, and in Sviridov's own summary of the cycle in his diaries. The eighth song, There Behind the Milky Hills' has many parallels with the imagery and language encountered in the fifth, Russia Cast Adrift" (from which the cycle derives its title): depictions of clouds, sky, flying, rising, leaping, surging upwards, radiance, exhilaration, and bright colours (gold, silver). In many ways, these songs work as counterparts, helping to establish a narrative that depicts Russia as a soaring, cosmic, spiritual entity that will ultimately outlive and transcend all historical abuses. However, it is in the final two songs of the cycle, $\mathrm{O}$ I Believe, I Believe, There is Happiness! ' and O Motherland, Happy and Irredeemable Hour!', that the theme of neverending faith in old Russia, and the sense of resurrection to former glory, is really brought to the fore. Sviridov himself described these final two songs thus:

The two last parts of the work have a solemn, hymnal character. They are filled with faith in the motherland, in her powerful, spiritual, creative forces. This music is of a solemn, pure, hymnal character, similar to the ancient hymns. The broad, hymn-like melody is accompanied by a developing piano part, towards the end of the work reaching a grandiose resounding of the pure, solemn ringing of bells [6].

This passage from Sviridov's diary emphasises some of the central thematic tropes of the cycle — the ringing of bells, the solemnity of tradition and orthodoxy, and a quasireligious faith in which a passionate undying belief in the native Russian land takes the place of devotion to God. In Russia Cast Adrift, Sviridov has created an artwork which, through its use of religious allegory, is a response to the legacy of the revolutionary upheaval, to what might be described as a Soviet betrayal' of Rus', but which is also simultaneously an evocation of Rus' itself — a bucolic, patriarchal, traditional Russian way of life that will resurrect and outlive all political regimes, because it is alive in the land itself: in the rivers, forests, fields, steppes, birds, people, in the very soil of Sviridov's Rus'.

\section{CONCLUSION}

Such an interpretation helps to situate Sviridov's artistic output within the social and cultural context in which he lived and composed. Moreover, it allows for a more nuanced characterisation of Sviridov and his music than is commonly accepted in English-language musicology, where he is more-often-than-not presented as a reactionary establishment figure who, in the words of Gerard McBurney, was motivated by a simple desire to retreat from the present $^{6}$ [9]. McBurney, it seems, is right in one sense: Sviridov not only adopts a neo-romantic musical language, but fully shrouds himself in pre-revolutionary ideology and culture. True, this may easily be interpreted as a selfimposed exile into the 19th century, but to say that he was motivated by a desire to retreat from the present" is severely to downplay Sviridov's engagement with the Russian nationalist movement of his own era. McBurney's assertion of retreating ' is in fact quite opposite to what Sviridov seems to have been attempting: namely a thorough critical engagement with contemporaneous Soviet society and national culture.

\section{REFERENCES}

[1] Merriam-Webster's Encyclopaedia of Literature, (Springfield, Massachusetts, Merriam-Webster, 1995).

[2] S. Cosgrove. Russian Nationalism and the Politics of Soviet Literature: The Case of Nash Sovremennik 1981-91 (Basingstoke, Palgrave Macmillan, 2004).

[3] Y. M. Brudny. Reinventing Russia: Russian Nationalism and the Soviet State 1953-1991 (Cambridge, Massachusetts, Harvard University Press, 1998).

[4] S. Zalygin. Sobesedovaniya (Moscow, Molodaya gvardiya, 1982), as quoted in [3], p. 77.

[5] V. Zubok. Zhivago's Children: The Last Russian Intelligentsia (Cambridge, Massachusetts, First Belknap Press of Harvard University Press, 2009).

[6] G. Sviridov. Music as Destiny[Muzïka kak sud'ba] (Moscow, Molodaya gvardiya, 2002). 
[7] Transcribed from the audiobook, M. Sixsmith, Russia: The Wild East, Vol. I (BBC Digital Audio, 2017).

[8] R. Taruskin. Defining Russia Musically (Princeton, New Jersey, Princeton University Press, 1997).

[9] G. McBurney. Soviet Music after the Death of Stalin: The Legacy of Shostakovich', in C. Kelly and D. Shepherd (eds.), Russian Cultural Studies (Oxford, New York, Oxford University Press, 1998), pp. 120138. 